\title{
Implementation of Task-Centered Design in a Web-Based Catalogue
}

\author{
Rina Yulius ${ }^{1}$, Fandy Neta ${ }^{2}$, Muchamad Fajri Amirul Nasrullah, S.ST., \\ M.Sc ${ }^{3}$, Muhammad Fikri Addin Rambe ${ }^{4}$ \\ ${ }^{1}$ Informatics Department, Politeknik Negeri Batam, Indonesia \\ ${ }^{2}$ Informatics Department, Politeknik Negeri Batam, Indonesia \\ ${ }^{3}$ Informatics Department, Politeknik Negeri Batam, Indonesia \\ ${ }^{4}$ Informatics Department, Politeknik Negeri Batam, Indonesia \\ Corresponding Author's Email: fandyneta@polibatam.ac.id
}

\begin{abstract}
E-catalogue is an optional way to facilitate the process of marketing in a company and increase its revenue. Its digital form allows a company to perform regular updates quickly and easily at zero cost, ensuring the accuracy of product data when it is presented to customer. Unlike conventional catalogs, e-catalogs facilitate a direct relationship between the company and its customers. The benefit of the e-catalog should be felt by both company and customers. Unfortunately, designing an ideal e-catalog that can give mutual benefit for company and customers is relatively tricky. It's easy for e-catalog product data to become messy and inconsistent. It's tedious and time-consuming to continuously update and manage the data. This study aims to design a standardized web-based catalog using task-centered design to give more benefits for the company and customers. By using a well-structured questionnaire, data were obtained from both company and customers. The questionnaire was developed using a modified-Nielsen's usability testing model. This model considers several factors that influence the usability of a system namely learnability, efficiency, memorability, errors, and satisfaction. Of the overall indicators, the average number of user satisfaction is $86.72 \%$ (minimum threshold $=80 \%$ ) which means the web-based catalog is very feasible. Therefore, it can be concluded that the e-catalog can be well-received by the company and its customers.
\end{abstract}

Keywords: e-catalog, task-centered design, usability

\section{INTRODUCTION}

Information technology has been widely used in the procurement of goods or services. One of the important parts of the electronic procurement system is the product catalog module (e-catalog). E-catalogue is a place for storing electronic information about a product or service that contains a list of goods, specifications, and prices for an online product [1]. E-catalog plays a basic part in e-procurement marketplaces. It can be used in both the offering and the obtaining forms. Companies utilize e-catalog to give some information to their business partners. Suppliers utilize e-catalog to portray merchandise or administrations that they 
offer for sale. Meanwhile, buyers may utilize e-catalog to indicate the things that they need to purchase

According to a marketing informant, one of the procurement companies for the sale of extinguishers in Batam, Indonesia, the marketing media for fire extinguishers products is the product catalog book. The customer must come directly to see the goods and negotiate prices according to the agreement of both parties. It is time-consuming and high-cost mechanism. This study aims to design a standardized web-based catalog using task-centered design to give more benefits for the company and customers. The prototype of the e-catalog application interface is designed to accommodate online product and price quoting processes easily searchable via the internet through a web browser that has been agreed by both parties. This method was chosen because it is quite effective in completing the creation of a device interface.

\section{LITERATURE REVIEW}

E-catalog is a list of information about goods, products or services made electronically that can be accessed online. E-Catalogue is an electronic document that lists item names, prices, then product specifications such as brand, type, size and other specifications in detail and provides information on the use of a product in the form of a product description. E-Catalogue can be accessed by customers and partner partners through the internet. Purchases and orders are made by selecting items from an online catalog, and providers can accept purchase orders as electronic orders in the market which increase efficiency in the procurement process[1].

Some previous studies of e-catalog were conducted as follows. [2] determined how much the appeal of e-catalog for suppliers and what is required to form the e-catalog more attractive to suppliers since as it were a modest bunch of suppliers that have taken part within the e-catalog. Meanwhile, [3] successfully designed CATaLog, an online framework that reduces retrieval time while users searching for a product in the catalog. Furthermore, [4] used a comparative study of the usability of an online catalog. User interfaces were assessed in terms of search speed, accuracy, efficiency, and user satisfaction.

This study implemented a task-centered design approach to develop the ecatalog. Task-centered design is a process where designers articulate concrete descriptions of real-world people doing their real-world tasks; use these descriptions to determine which users and what tasks the system should support; prototype an interface that satisfies these requirements, and evaluate the interface by performing a task-centered walkthrough [5]. There are 4 steps in task-centered design: identification, user-centered requirement analysis, design through the scenario, and evaluation. Tasks can be decomposed into more and more specific and well-defined tasks that can later be turned into workflows that can be executed [6]. 


\section{METHODOLOGY}

1) Research Model

In this study, the task-centered design approach was implemented to design the e-catalog. Task-centered design is a technique that helps developers design and evaluates interfaces based on users' real-world tasks. It is a very effective usability engineering method suitable for many interface development problems. Two-phase testing was designed to evaluate the interface of e-catalogue. The first phase is black-box testing to examine the functionality of the catalog. Hereafter, the usability of the design was evaluated using a modified-Nielsen's usability testing model [7]. In this phase, participants were asked to evaluate the e-catalog interface in terms of its overall usability using instruments that have been developed (modifiedNielsen's model)

2) Instruments and Participants

This study was quantitative research, particularly a survey technique using a questionnaire. It was carried out in several places in Batam. A total of 30 respondents were randomly asked to contribute to this study. All of the respondents were required to complete a Likert-scale questionnaire. Finally, frequencies analysis (percentages of responses in each category) was implemented to analyze the Likert-scale data.

\section{RESULTS AND DISCUSSION}

Implementation of e-Catalog design produces an interface in accordance with the stages of manufacture with the Task-Centered System Design method as illustrated in Figure 1.

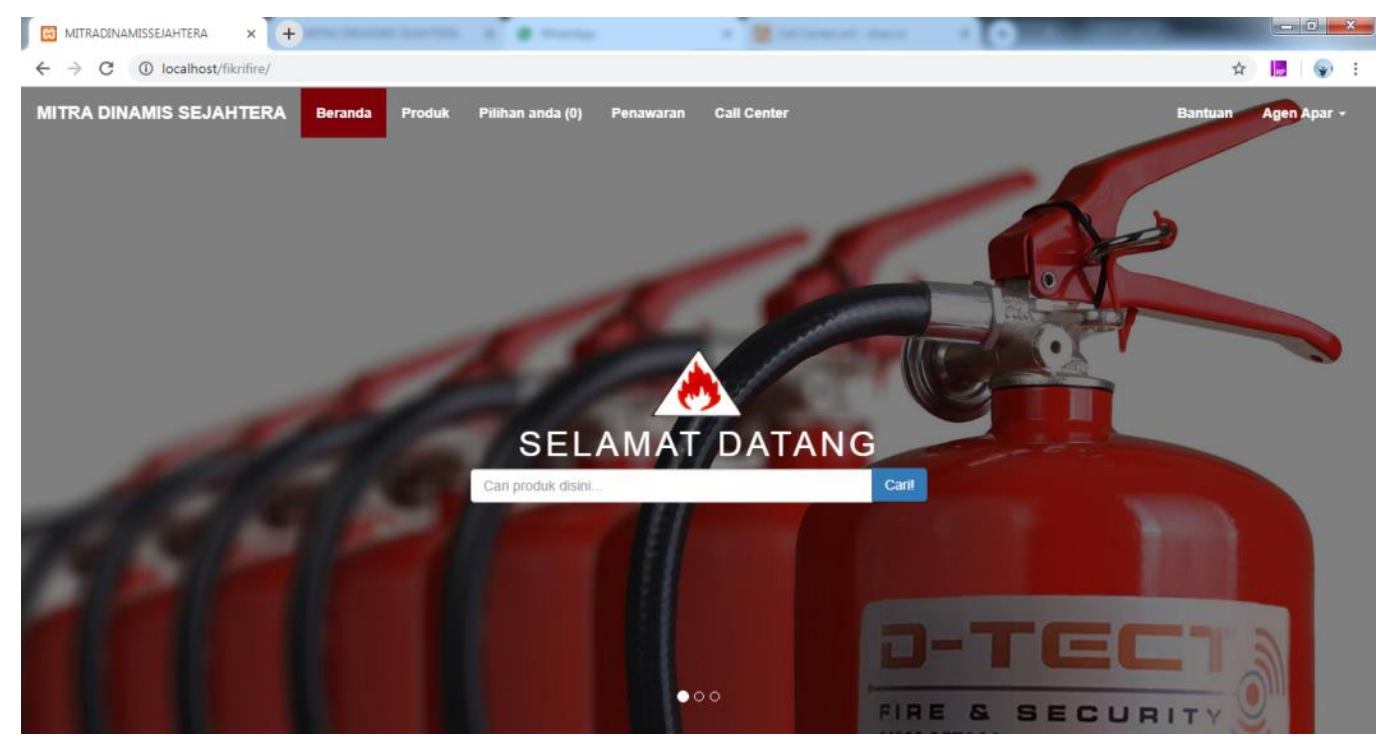

Figure 1. Implementation result of e-catalog interface

Evaluation results of black-box testing showed that all of 17 functional proposed on the e-catalog system was succeed as depicted in Table 1 
Table 1. Results of Black-box Testing

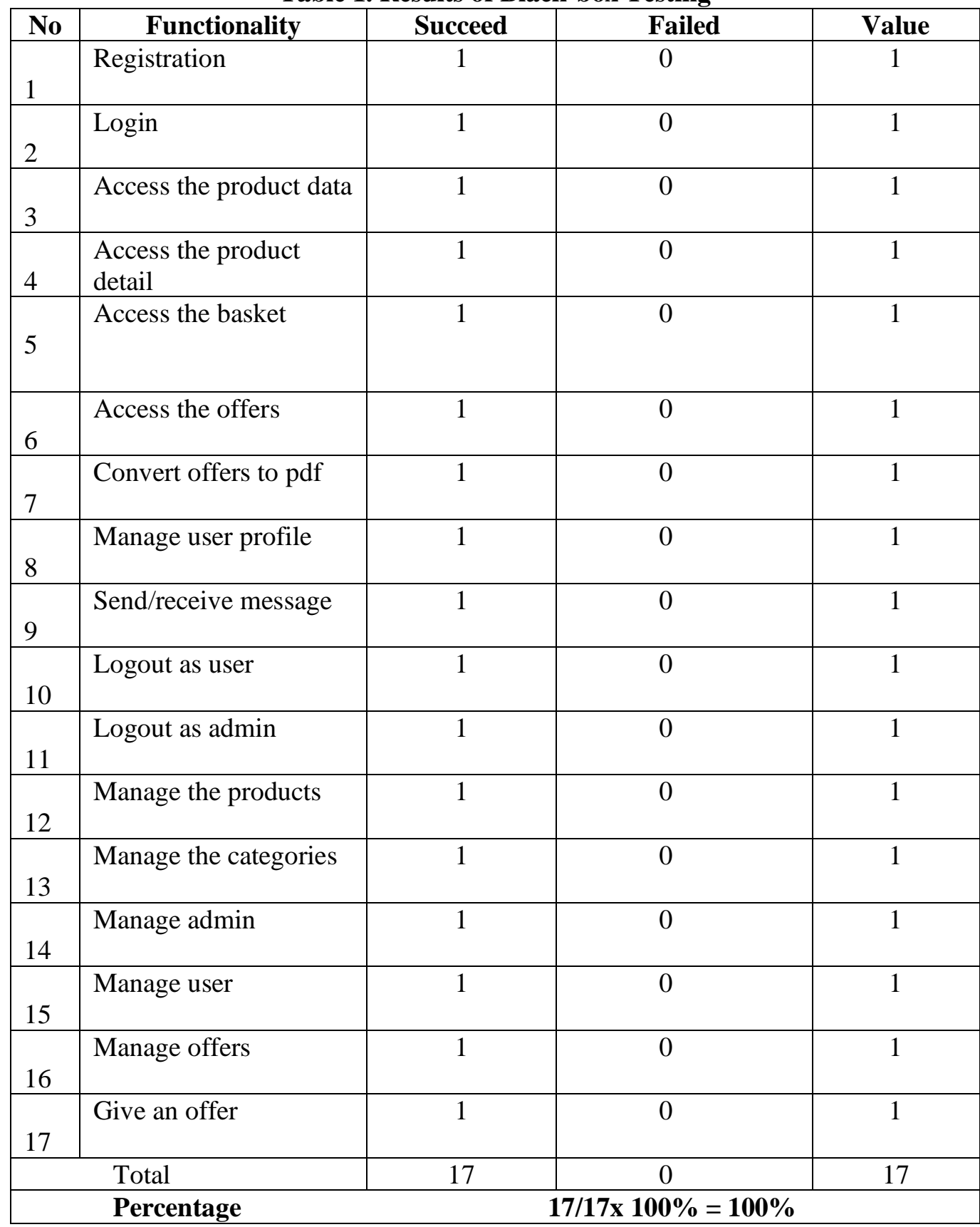

Usability testing was conducted by direct testing of the e-Catalog interface to the 30 respondents. After conducting the interface test the respondents filled out the questionnaire as an evaluation of the e-Catalog interface testing consisting of 14 statements of 5 usability variables. The results of the usability testing questionnaire were calculated using interval index values using a Likert-scale as illustrated in table 2 . 
Table 2. Results of Usability Testing

\begin{tabular}{|c|c|c|c|}
\hline No & Variable & Results (\%) & Index of Interval \\
\hline 1 & Learnability & 87.56 & Very good \\
\hline 2 & Efficiency & 86.89 & Very good \\
\hline 3 & Memorability & 85.67 & Very good \\
\hline 4 & Errors & 85.67 & Very good \\
\hline 5 & Satisfaction & 87.83 & Very good \\
\hline & Average & 86.72 & Very good \\
\hline
\end{tabular}

From the overall results of the usability test conducted, the average of all available variables is taken, then the average number of user satisfaction is $86.72 \%$ which is calculated by Likert-scale according to the interval index number $>80 \%$ which means the design of the e-catalog is very feasible.

\section{CONCLUSION}

Based on the results of the study it can be concluded that the making of the e-Catalog interface prototype using the Task-Centered System Design method was successful as expected. Usability interface values are very feasible with an average value of user satisfaction reaching $86.72 \%$ (Learnability $87.56 \%$, Efficiency $86.89 \%$, Memorability $85.67 \%$, Errors $85.67 \%$, Satisfaction $87.83 \%$ ).

\section{ACKNOWLEDGMENT}

This study was supported by the Center for Research and Community Service of Politeknik Negeri Batam. We thank our colleagues from the Department of Informatics Engineering of Politeknik Negeri Batam who provided insight and expertise that greatly assisted the research.

\section{BIODATA}

Rina Yulius is a lecturer of the Informatics Engineering Dept on Politeknik Negeri Batam, Batam, Indonesia. She has a research interest in gamification, humancomputer interaction, and UX/UI.

Fandy Neta is a lecturer in video editing, photography, and graphic design in Informatics Engineering Dept, Politeknik Negeri Batam, Indonesia.

Muchamad Fajri Amirul Nasrullah is a lecturer of mobile programming and videography in the Informatics Engineering Dept, Politeknik Negeri Batam, Indonesia.

Muhamad Fikri is a student of Informatics Engineering Dept, Politeknik Negeri Batam, Indonesia. 


\section{REFERENCES}

[1] D. Endianingsih, "Peran e-Catalogue dalam Proses Pengadaan Elektronik," J. Kalibr., vol. Vol. 13, no. 1, pp. 1-7, 2015.

[2] H. Hudrasyah, M. Yusuf, C. Nugraha, I. Fatima, R. A. Rahadi, and C. Nugraha, "e-Catalogue Attractiveness Study to Increase Suppliers Participation," Int. J. Accounting, Financ. Bus., vol. 4, no. 20, pp. 14-31, 2019.

[3] S. Pal, M. Zampieri, S. K. Naskar, T. Nayak, M. Vela, and J. Van Genabith, "CATaLog online: Porting a post-editing tool to the web," Proc. 10th Int. Conf. Lang. Resour. Eval. Lr. 2016, no. 599, pp. 599-604, 2016.

[4] E. Callahan and J. Koenemann, "A comparative usability evaluation of user interfaces for online product catalog," pp. 197-206, 2000.

[5] S. Greenberg, "Working Through Task-Centered System Design," Diaper, D. Stanton, N. Handb. Task Anal. Human-Computer Interact., pp. 49-66, 2004.

[6] Y. Gil, F. Michel, V. Ratnakar, and M. Hauder, "Organic data science: a task-centered interface to on-line collaboration in science," Proc. ACM ..., pp. 2-5, 2015.

[7] B. J. Nielsen et al., Return on Investment (ROI) for Usability, 4th ed. Nielsen Norman Group. 